American Journal of Applied Sciences 8 (6): 540-546, 2011

ISSN 1546-9239

(C) 2011 Science Publications

\title{
The Role of Home Stay for Ecotourism Development in East Coast Economic Region
}

\author{
Md. Anowar Hossain Bhuiyan, Chamhuri Siwar, \\ Shaharuddin Mohamad Ismail and Rabiul Islam \\ Institute for Environment and Development, University Kebangsaan Malaysia, \\ 43600 UKM Bangi, Darul Ehsan, Selangor, Malaysia
}

\begin{abstract}
Problem statement: This study provided a brief discussion of home stay for ecotourism development in ECER. Home stay is a potential economic activity in tourism sector. The East Coast Economic Region (ECER) has numerous ecotourism resources including hills, mountains, lakes, waterways, state and national parks, recreational forest parks and forest reserves. Home stay should emphasize on the cultural practices as well as to create a genuine interest and commitment among the local people in the region. The study of this study focused the potentialities of home stay for ecotourism development in ECER. The study also discussed the short comings and necessary actions for developing home stay activities in this region. Approach: The data for analysis was perceived from the secondary sources. The significant manipulations for acquired data were home stay accommodation on ECER. Results: There are some potential factors were remaining in the ECER for establishing home stays-ecotourism resources and biodiversity, infrastructure development, integrated approach, present the cultural performance, limited environmental and social impact, commercial interest and investment and opportunities for local entrepreneurs. Some weaknesses also remain in ECER for home stays development. These are low standard of accommodation, unacceptable bathroom and toilet facilities, identity for each Home stay, lack of hospitality experience, marketing problem and lack of campaign. There are some challenges such as brand image issues, meeting international standards, training facilities, marketing and promotion, poverty alleviation must be consider for home stay development in ECER. Conclusion: The study revealed that home stays operation could be create alternative accommodation opportunities in ECER. With proper planning and implementation, operational regulation and management, appropriate development and financial allocation in home stay operation would be ensuring sustainable ecotourism development in ECER.
\end{abstract}

Key words: Home stay, ecotourism development, economic growth, tourism development, accommodation capacity, East Coast Economic Region (ECER)

\section{INTRODUCTION}

Home stay is a new idea for accommodation in the tourism industry. It is a potential economic activity in tourism sector. It becomes popular to the tourists who desire to know and interact with the local people, cultural attractions, social cohesion, natural resources and ecosystem (LTSN Hospitality, Leisure, Sport and Tourism, 2003). Locally owned and operate home stays constitute a suitable tourist accommodation for the local community to participate in tourism activities (Wall and Long, 1996). Studies have shown that economic considerations have been the primary motivating force for the local people to become involved in tourism development. With the increase in tourists, more local houses became home stays operation which appeal to the budget tourists because of price (Hinch and Butler, 1996). Initially in a country, operating home stays was not regarded as an economic activity and the local governments paid little attention to it. When tourists arrival increasing in a tourism area, then both the local government and the county government encouraged the local people to operate home stays which could accelerate economic growth. By this time, the local people regarded home stay operation as an occupation and provided rooms and facilities to tourists. To enlarge accommodation capacity, home stay operators built two or three additional rooms in their yards for tourists ( $\mathrm{Gu}$ and Wong, 2010).

Corresponding Author: Chamhuri Siwar, Institute for Environment and Development, University Kebangsaan Malaysia, 43600 UKM Bangi, Darul Ehsan, Selangor, Malaysia 
Tourism sustainability not only concerns resource conservation and environment protection but also the local community's welfare. The money making activities of tourism has the potential to the local economy and bring tourist taxes for state and federal governments provided that policies and guidelines are established in ensuring the sustainable development (Yassin et al., 2010). Several types of conflicts resulted from the different impacts of hotels and home stays on the local environment and ecosystem. The hotel developers have cut down trees by the local people to build hotels, removed sand from the beach for construction and generated large amounts of solid waste and waste water. By contrast, the local people including home stay operators has planted the trees, protected the land and generated less waste. The second conflict is about beach management. The home stay operators are never involved in the activities of beach management. By contrast, the hotel developers are empowered by the government to manage the beach and impose charge an entrance fee for users. The local people including the home stay operators believe this will reduce accessibility to the beach and reduce the number of tourists (Gu and Wong, 2010). Tourism enterprise may be sustainable by dealing with the conservation of local cultures and customs. It is necessary to establish the network adjusting the local government and community people with knowledge and understanding of tourism (Saeng-Ngam et al., 2009). The county government believed that home stays, which have limited accommodation capacity and limited facility and service quality, are appropriate for the early stage of tourism and will hinder the largescale resort operation. Community involvement in home stay operation provides job opportunity and improves local quality of life.

Malaysian tourism industry has been growing considerably in recent years. On the world scale Malaysia, is ranked 31st, with good ground transport infrastructure and excellent price competitiveness (Mohebi and Rahim, 2010). In Malaysia, the home stay establishments that have emerged recently do not have such a traditional reliance on geographical proximity to major tourism attractions and establishments for clientele sources. As a part of government rural development initiatives, they are typically village-based and sustain themselves as independently, usually using local endowments such as social elements, cultural motifs and natural resources. The home stay program in Malaysia was initially promoted to provide tourists with cultural experiences of Malaysia's multi-ethnic lifestyles and economic benefits to the local communities. Malaysia expresses a desired multi- cultural manifestation from its tourism products. By the end of 2000, there were 612 home stay operators scattered in 31 Malay villages registered with the Ministry of Cultural, Arts and Tourism (MOCAT). However, the MOCAT give emphasize to the promotion and incorporation of the home stay program as one of Malaysia's main tourism attractions (Liu, 2006).

The availability of sufficient space, the security of the home structure and level of quality, safety and suitability, are important elements for eligibility to be a home stay operation. The revenue from home stay operation is substantial when considering the villagers' moderate way of living which requires relatively low household income for their daily needs. There are no particular expectations of advancing knowledge and skills regarding the home stay operations, because of highly amateur involvement and, thereby, the limited obligations perceived. The village itself is a social and ethnic enclave. Most villagers have not been tourists themselves nor have they ever been exposed to foreign cultures. Visitors are urged to follow the hosts' way of living and, in fact, their awkwardness in imitation was found by the hosts to be entertaining. Home stay guests tend to be more culturally aware and sensitive as a result of their visit (Liu, 2006).

Ecotourism is seen as a tool to empower indigenous communities in an area (Sofield, 2003). Many ecotourism sites, such as national parks and protected areas, are located in remote areas which have rich ecological and biological diversity and indigenous cultures (Hawkins and Lamoureux, 2001; Nepal, 2000). Ecotourism's goal is to achieve conservation and community development through the provision of economic and social incentives to local communities for their well-beings (Chapman, 2003; Ross and Wall, 1999). Cater (1994) and Wild (1994) suggest that ecotourism which encourages local employment and small business development promotes higher economic multipliers and that a community approach to decisionmaking helps to ensure traditional lifestyles and community values and traditions are respected. Local attitude toward the key dimensions of ecotourism development helps planners or project managers understand how community members feel about utilizing ecotourism as a means to balance conservation and development (Lai and Nepal, 2006). Tourism attitude research has shown that economic benefits generated from ecotourism, including employment opportunities, tourism revenues, infrastructure improvement and foreign exchanges are frequently the reasons driving local communities for ecotourism development (Archer and Cooper, 1998; Lindberg, 
2001). Participation in village government committees, conservation activities, tourism-revenue-sharing programs and other planning and management programs are reported the affect of local people on tourism areas (Mehta and Heinen, 2001).

The East Coast Economic Region (ECER) has numerous ecotourism resources including well-known hills such as Cameron Highlands, Fraser's Hill, Genting Highlands; mountains like Gunung Stong and related attractions at Gua Musang. There are also lakes and inland waterways at Tasik Kenyir in Terengganu, Tasik Bera and Tasik Chini in Pahang, as well as State and National Parks such as Taman Negara and Endau Rompin. Other ecotourism attractions include Rantau Abang, Kenong Rimba Forest Park, Gunung Benom, Cemerong Forest Reserve, Lojing and Sungai Perias. Home stay activities can build up in this region on the basis of ecoyourism resources.

Home stay operations have become popular in rural areas because of Malaysia's development orthodoxy which gives higher priority to the economic enhancement of kampungs (village) (Clammer, 1996; Kennedy, 1993). The ECER attracted an estimated total of 7.3 million hotel guests in 2005, out of which 2.5 million were foreign guests. In the context of poverty reduction, the concept of Pro Poor Tourism could be applied in the ECER to formulate strategies to empower rural and remote communities. Pro Poor Tourism strategies are aimed at empowering the target groups economically, socially and psychologically. Thus it is essential that programs such as the home stay should emphasize on the revitalization of cultural practices and rituals, to be showcased to tourists as well as to create a genuine interest and commitment among the local youth in the region (ECER Master Plan, 2007). The present study focuses the potentialities of home stay for ecotourism development in ECER. The study also discusses the short comings and necessary actions for developing home stay activities in this region.

\section{MATERIALS AND METHODS}

Data attainment: The study is conducted in University Kebangsaan Malaysia, Bangi since January, 2010 to December, 2010. The data for analysis is perceived from the secondary sources. The significant manipulations for acquired data are home stay accommodation on East Coast Economic Region (ECER), Malaysia. The corresponding outcomes are demonstrated from the analysis of collected data.

Home stay: Home stay accommodation is a term related with cultural associations. In Australia the term is particularly associated with farmhouse accommodation and in the United Kingdom, it is particularly associated with the English as a Foreign Language Sector. As a generic term it is used to refer to types of accommodation where visitors or guests pay directly or indirectly to stay in private homes. It embraces a range of accommodation types including farm stay accommodation, host families, some small hotels and bed and breakfasts. Accommodation such as guest houses, boarding houses, lodging houses whose terms are sometimes used synonymously with hotels and bed and breakfasts are also included as home stay accommodations (LTSN Hospitality, Leisure, Sport and Tourism, 2003). Home Stay referred to living place since it was one type of tourism based on accommodation centered. It would be guidelines for improving, enhancing and promoting the local community as well as including the economic, social and cultural aspects with sustainable existence as well (Chaiyatorn et al., 2010).

In Table 1 shows the distribution of Home Stay Participants according to States in Malaysia. There was 277, 47 and 60 home stay operating in the three states of ECER-Pahang, Terengganu and Kelantan respectively.

Table 2 shows that additional number of accommodation rooms required by states in the ECER. The total estimated number of hotel rooms by 2020 is 130,132 with an additional requirement of 98,973 for the region. The additional requirement for rooms is $19,475,29,846$ and 49,652 for Kelantan, Terengganu and Pahang respectively until 2020.

Table 1: Distribution of home stay participants according to states in Malaysia

\begin{tabular}{lc}
\hline State & $\begin{array}{c}\text { Number of } \\
\text { home stay }\end{array}$ \\
\hline Selangor & 480 \\
Sabah & 212 \\
Kedah & 51 \\
Langkawi & 60 \\
Sarawak & 56 \\
Johor & 42 \\
Pahang & 277 \\
Terengganu & 47 \\
Pulau Pinang & 23 \\
Negeri Sembilan & 122 \\
Melaka & 52 \\
Kelantan & 60 \\
Perak & 8 \\
Perlis & 12 \\
Labuan & 22 \\
Total & 1,089 \\
\hline
\end{tabular}

Source: Ministry of Tourism, Malaysia, 2005 
Ecotourism: According to the definition ecotourism is "responsible travel to natural areas that conserves the environment and improves the well-being of local people". It is one of the fastest and growing sectors of the global tourism industry. The common core precepts of ecotourism are conservation of natural and cultural heritage; empowerment and provision of financial benefits for local communities; minimal environmental impact; environmental and cultural education and respect for tourists (Ah-Choy, 2010). Effectiveness of ecotourism as a socioeconomic and environmental tool is depending on equitability of income distribution among the local communities.

East coast economic region: The East Coast Economic Region (ECER) consists of three statesKelantan, Terengganu, Pahang and District of Mersing in Johor. It covers $51 \%$ of the land area of Peninsular Malaysia and represents $14 \%$ of the national population.

Table 2: Additional number of accommodation rooms in the ECER

\begin{tabular}{llll}
\hline Year & 2005 & 2020 & $\begin{array}{l}\text { Additional rooms } \\
\text { required }\end{array}$ \\
\hline Kelantan & 3,462 & 22,937 & 19,475 \\
Terengganu & 6,402 & 36,248 & 29,846 \\
Pahang & 21,295 & 70,947 & 49,652 \\
Total & 31,159 & 130,132 & 98,973 \\
\hline
\end{tabular}

Source: Tourism malaysia (2007)

Table 3: Distribution of home stays in the ECER

\begin{tabular}{ll}
\hline State & Villages \\
\hline Kelantan & Kampung Pantai Seri \\
Terengganu & Kampung Baru, Gua Musang \\
& Kampung Rhu 10 \\
Pahang & Kampung Baru Penarik \\
& Kampung Pasir Raja \\
Kg. Desa Murni & Kg. Bangau Tanjung \\
Kg. Megat Segama \\
Kg. Peragap \\
Kg. Ketam \\
Kg. Tenggara \\
Kg. Seberang Temerloh \\
Kg. Kerdau \\
Seri Semantan \\
Bukit Fraser \\
Tanah Rata \\
Sg. Pasu, Raub \\
Kg. Sibar, Kuala Lipis \\
PPSK Rumpun Makmur, Kuala Krau \\
Kg. Belimbing, Kuantan \\
FELCRA Sri Makmur \\
Mukim Penyor 1, Pekan \\
FELCRA Sg. Ternau \\
PPSK Tembeling Tengah \\
Kuala Medang \\
\hline Source: ECER master plan $(2007)$
\end{tabular}

Source: ECER master plan (2007)
A Master Plan was developed and will be the basis for guiding the development of this region over the next 12 years where it will be transformed into a major international and local tourism destination, an exporter of resource based and manufactured products, a vibrant trading centre and an infrastructure and logistics hub. The ECER's distinctive natural resources, culture and heritage will form the basis for transforming the economy into one that is dynamic and competitive in light of greater regional and global competition and economic liberalization (ECER, 2010).

The Table 3 reveals that there are only 3 villages participating in the home stay program in Kelantan and Terengganu. Although the number of villages and providers participating in the home stay program, in Pahang is the biggest among other states in Malaysia.

\section{RESULTS}

In Table 4 shows the total number of home stay participants in Malaysia. There were about 286 and 321 houses participating officially in home stay program throughout the country in the year of 1997 and 1998 respectively. The number of participants rose to 776 by 2002 . There were 948 participants in 2004 and 1089 in 2005.

The projected demand for accommodation by state in ECER is shown in Fig. 1. The projected number of accommodation will be 2511565,3969125 and 18066861 in Kelantan, Terengganu and Pahang by 2020.

The projected number of accommodation rooms by state capital is shown in Fig. 2. The total number of accommodation rooms is projected to be 20,643, 25,373 and 41,248 in Kota Bharu, Kuala Terengganu and Kuantan until 2020.

Table 4: Total number of home stay participants in Malaysia, 1997-2005

\begin{tabular}{lc}
\hline Year & $\begin{array}{c}\text { Total number } \\
\text { of home stay }\end{array}$ \\
\hline 1997 & 286 \\
1998 & 321 \\
2002 & 776 \\
2004 & 948 \\
2005 & 1089 \\
\hline
\end{tabular}

Source: Ministry of tourism, Malaysia (2005)

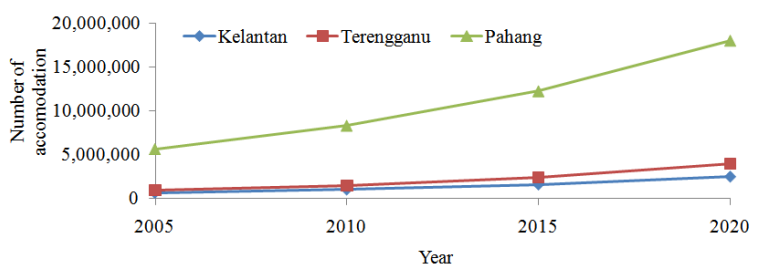

Fig. 1: Projected demand for Accommodation by state in ECER 
Am. J. Applied Sci., 8 (6): 540-546, 2011

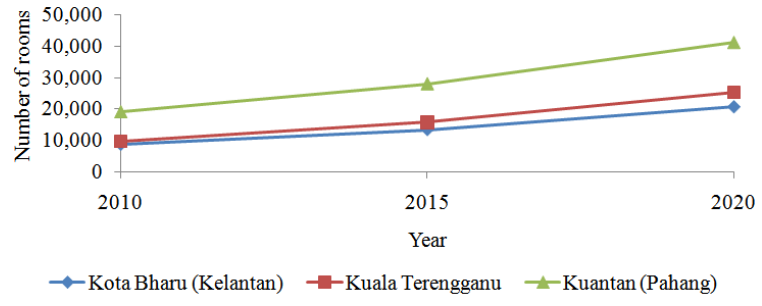

Fig. 2: Projected accommodation rooms by state capital

\section{DISCUSSION}

Ecotourism is one of the boosting and promising tourism segmentation in the world today. Many countries of the world build up their economic advancement by using this types' tourism. Ecotourism has minimum negative impact on the environment. It is economically, socially and environmentally sustainable. Tourists want to stay closely with the local communities of the ecotourism sites. They can know the traditions and cultures of the local area as well as natural beauties of the tourism places. Home stay can give better chance to the tourists for enjoying this advancement. ECER has suitable conditions to develop home stays in the ecotourism sites of this region. In this context, there are some potential factors are remaining in the ECER for establishing home stays.

Ecotourism resources and biodiversity: ECER is full of natural resources and rich niche of biodiversity. These are suitable for ecotourism and home stay development in this area. Home stays give opportunities to the tourists for staying closely in the ecotourism sites.

Infrastructure development: ECER has huge opportunities for building home stays in this region. MOTOUR has involved in improving the physical infrastructure and the Ministry of Rural and Regional Development provides soft loans for home stay owners to improve the quality of their guestrooms.

Integrated approach: An integrated approach has been remaining in ECER for home stay development. Tourism Malaysia is promoting the home stay program in a general manner. Malaysian Homestay Association (MHA) focuses the marketing aspects while ECER Development Council provides the framework for proper integration among key stakeholders for the success of the home stay program in the region.

Present the cultural performance: Cultural performance is an integral component of the home stay program. Ministry of Tourism is funding for focusing cultural performance to operate successful home stays.

Limited environmental and social impact: Home stays have developed in a small scale. For developing this, need short space and limited involvement. So, home stay not polluted the environment hugely and negative social impact also few.

Commercial interest and investment: Home stays have been operating in ECER to attain commercial benefit. It also ensures investment opportunity for the accommodation businessmen.

Opportunities for local entrepreneurs: Local entrepreneurs in ECER can operate home stays easily by their limited capital. This can be exploited family businesses and stimulate the economy.

In spite of huge potentialities, some weaknesses also remain in ECER for home stays development.

Low standard of accommodation: Poor qualities of accommodations are major weakness of the home stay program in Malaysia as well as ECER. For the lacking of high standard accommodation, home stays not attract huge western tourists.

Unacceptable bathroom and toilet facilities: Toilets of home stays are identified as poor standard in quality. These are not comfortable and hygienic for the tourists.

Identity for each home stay: Another weakness for home stays is identity problem. Each home stay hasn't differentiation symbol for easily identified.

Lack of hospitality experience: The home stay labors are not so experienced in hospitality. Language difficulties between the guest and host family are another problem for home stay operation.

Marketing problem: Due to effective marketing, home stay business not flourish in an expected level. Little investment in professional marketing is barrier for home stay promotion.

Lack of campaign: Proper and prompt campaign are absent in home stays business. Comprehensive guidebook, IT based information are not available in this regard.

There are some challenges must be consider for home stay development in ECER. 
Brand image issues: Brand image is a key element to develop a strong destination of any business. Home stay not create strong brand image in accommodation sector. So, it is a great challenge to establish brand image of home stay for better opportunities.

Meeting international standards: Hotels and resorts always maintain international standard and facilities for customers' satisfaction. But home stay not enough concern in this regard. As a result, they haven't success for attracting huge foreigners.

Training facilities: Home stays operators are not so experienced and professional. For successful operation, skills training for home stay management courses, IT courses, e-booking courses are necessary.

Marketing and promotion: Target marketing should be carried out for home stay accommodation. Target market can flourish and expand the home stay business.

Key success factors: The success of home stay business depends on some factors- commitment and cooperation from the local people, good organization and strong leadership and proper marketing strategies and promotion.

Poverty alleviation: Rural agricultural and fishing communities need to be integrated with home stay development to allow for employment and small-scale entrepreneurial opportunities. So, home stay business must be considering the poverty alleviation issue.

\section{CONCLUSION}

Home stays operation can be create alternative accommodation system in ECER. This will ensure employment and income opportunity for local people as well as economic enhancement of the country. There are several steps may be taken to develop the home stays activities in ECER. They are as follows:

- To improve the quality of the houses which participating in the home stay program

- To maintain an integrated approach towards developing, managing and marketing the home stay program

- To involve the key stakeholders in the overall activities of home stay program

- To achieve a balance between the educational, entertainment and commercial elements of home stay
- To reach niche market segments attract to the home stay experience

- To improve the professionalism of the home stay owner for product development, management, operation and marketing

- To arrange training program for upgrading the service quality, taught to be proficient in English and foreign languages

- To certify the home stay in rating system according to their quality control and to encourage competition between home stay providers

Home stays operation is suitable for ecotourism development in ECER. Home stay may be developing as alternative accommodation in place of tourism. It will be helpful for flourishing ecotourism sites. Home stays can build up near the ecotourism sites and tourist wants to stay near the natural attractions.

The development of home stay may be driven by the Tourism Ministry, ECER Development Council, Malaysian Homestay Association (MHA) and local investors. Although, Government support will be essential for significant development of home stays. Public-private partnership between the government, ECER Development Council and private sector will be helpful for development this accommodation. Home stay accommodation in the ECER has great potential. With proper planning and implementation, operational regulation and management, appropriate development and financial allocation in home stay operation will be ensuring sustainable ecotourism development in ECER.

\section{ACKNOWLEDGEMENT}

Financial assistance provided from the Aras Perdana (AP) Research Grant, Institute for Environment and Development, University Kebangsaan Malaysia (Ref. No. UKM-AP-PLW-04-2010) led by Emeritus Professor Chamhuri Siwar is gratefully acknowledged.

\section{REFERENCES}

Ah-Choy, E., 2010. The nascent development of ecotourism in lagong hill. Am. J. Applied Sci., 7: 1528-1531. ISSN: 1546-9239

Archer, B. and C. Cooper, 1998. The Positive and Negative Impacts of Tourism. In: Global Tourism, Theobald, W.F. (Ed.). Butterworth-Heinemann, Oxford, pp: 63-81. ISBN: 0750640227

Cater, E., 1994. Ecotourism in the Third World: Problems and Prospects for Sustainability. In: Ecotourism: A Sustainable Option? Cater, E. and G. Lowman (Ed.). Wiley, Chichester, pp: 69-86. ISBN: 0-471-94896-9 
Chaiyatorn, S., P. Kaoses and P. Thitphat, 2010. The developmental model of cultural tourism homestay of the Lao Vieng and Lao song ethnic groups in the central region of Thailand. J. Soc. Sci., 6: 130-132. ISSN: $1549-3652$

Chapman, D., 2003. Management of national parks in developing countries-A proposal for an international park service, Ecol. Econ., 46: 1-7. ISSN: 0921-8009, DOI: 10.1016/S09218009(03)00105-8

Clammer, J., 1996. Values and Development in Southeast Asia. 1st Edn., Pelanduk Publications, the University of Michigan, ISBN: 10: 9679785688, pp: 228

ECER Master Plan, 2007. East Coast Economic Region Development Council. Kuala Lumpur. http://www.ecerdc.com/ecerdc/dc.htm

ECER, 2010. The East Coast Economic Region. http://www.ecerdc.com/ecerdc/about.htm

Gu, M. and P.P. Wong, 2010. Development of Coastal Tourism and Homestays on Dachangshan Dao, Liaoning Province, North East China. www.irfd.org/events/wfsids/virtual/papers/sids_mi ngpohpoh.pdf

Hawkins, D.E. and K. Lamoureux, 2001. Global Growth and Magnitude of Ecotourism. In: The Encyclopedia of Ecotourism, Weaver, D.B. (Ed.). CABI Publishing, New York, pp: 63-72. ISBN: 085199-368-0

Hinch, T. and R. Butler, 1996. Indigenous Tourism: A Common Ground for Discussion. In: Tourism and Indigenous Peoples, Butler, R. and T. Hinch (Eds.). International Thomson Business Press, London, pp: 3-21. ISBN: 0415125294

Kennedy, J., 1993. History of Malaya. 3rd Edn., S. Abdul Majeed and Co., Kuala Lumpur.

Lai, P. and S.K. Nepal, 2006. Local perspectives of ecotourism development in Tawushan Nature Reserve, Taiwan. Tourism Manage., 27: 11171129. DOI: 10.1016/j.tourman.2005.11.010

Lindberg, K., 2001. Economic Impacts. In: The Encyclopedia of Ecotourism, Weaver, D. (Ed.). CABI Publishing, New York, pp: 363-377. ISBN: 0-85199-368-0

Liu, A., 2006. Tourism in rural areas: Kedah, Malaysia. Tourism Manage., 27: 878-889. DOI: 10.1016/j.tourman.2005.05.007
LTSN Hospitality, Leisure, Sport and Tourism, 2003. Resource Guide: Homestay Accommodation Sector. http://www.heacademy.ac.uk/assets/hlst/documents/ projects/benchmarking/benchmark_diss_results.pdf

Mehta, J. and J. Heinen, 2001. Does community-based conservation shape favorable attitudes among locals? An empirical study from Nepal. Environ. Manage., 28: 165-177. DOI: 10. 1007/s002670010215

Mohebi, M. and K.A. Rahim, 2010. Revenue determinants in tourism market. Am. J. Applied Sci., 7: 1593-1598. ISSN: 1546-9239

Nepal, S.K., 2000. Tourism, National Parks and Local Communities. In: Tourism and National Parks: Issues and Implications, Butler, R.W. and S.W. Boyd (Ed.). Wiley, New York, pp: 73-94. ISBN: 978-0-471-98894-6

Ross, S. and G. Wall, 1999. Ecotourism-toward congruence between theory and practice. Tourism Manage., 20: 123-132. DOI: 10.1016/S02615177(98)00098-3

Saeng-Ngam, A., S. Chantachon and P. Ritthidet, 2009. The organization of cultural tourism by the community people in the region of Toong Kula Rong Hai. J. Soc. Sci., 5: 342-347. DOI: 10.3844/jssp.2009.342.347

Sofield, T.H.B., 2003. Empowerment for Sustainable Tourism Development. 1st Edn., Emerald Group Publishing, Boston, ISBN: 10: 9780080439464 , pp: 401.

Wall, G. and V. Long, 1996. Balinese Homestays: An Indigenous Response to Tourism Opportunities. In: Tourism and Indigenous Peoples, Butler, R. and T. Hinch (Eds.). International Thomson Business Press, London, pp: 27-48. ISBN: 0415125294

Wild, C., 1994. Issues in Ecotourism. In: Progress in Tourism, Recreation and Hospitality Management: Volume 6, Cooper, C.P. and A. Lockwood (Eds.). Wiley, Chichester, pp: 12-21. ISBN: 10: 0471948594

Yassin, S.M., H.A.M. Shaffril, M.S. Hassan, M.S. Othman and A.A. Samah et al., 2010. Prospects of waterway development as a catalyst to improve regional and community socio-economy level, Am. J. Econ. Bus. Admin., 2: 240-246. DOI: 10.3844/ajebasp.2010.240.246 